\title{
Recenzja książki Jakuba Bornio, Bezpieczeństwo narodowe Polski w kontekście kryzysu ukraińskiego. Wymiar polityczno-militarny, Wydawnictwo Difin, Warszawa 2019, ss. 416
}

Badania nad zjawiskiem bezpieczeństwa narodowego Polski w kontekście zagrożeń politycznych i militarnych jako konsekwencji konfliktu rosyjsko-ukraińskiego zasługują na uwagę. Przedłożona do recenzji książka autorstwa Jakuba Bornio, specjalizującego się w omawianej problematyce, na pewno wzbogaci polski rynek wydawniczy w całościową publikację dotyczącego tego obszaru.

Recenzowana książka to praca istotna zarówno ze względu na podejmowaną tematykę, formę prezentowanych zagadnień, jak i popularnonaukowy wymiar. Problematyka stosunków międzynarodowych na obszarze Europy Wschodniej, a także polityka bezpieczeństwa stanowią często eksplorowany obszar badań w zakresie nie tylko politologii, ale również innych dziedzin naukowych. Należy zgodzić się z Autorem, że bezpieczeństwo Polski w wymiarze politycznym i militarnym w XXI wieku nie było bezpośrednio zagrożone, bowiem jak zauważa Bornio, od okresu zimnowojennego Polska nie doświadczyła żadnego konfliktu zbrojnego w swoim najbliższym sąsiedztwie (za wyjątkiem konfliktu w Gruzji w 2008 roku, czy konfliktu w byłej Jugosławii w latach dziewięćdziesiątych XX wieku, które nie miały bezpośredniego przełożenia na stan bezpieczeństwa naszego państwa w porównaniu z obecnym kryzysem na Ukrainie).

Specyfika obszaru sąsiedzkiego, a zwłaszcza kontekst agresywnej polityki Rosji czy szerzej rywalizacji rosyjsko-zachodniej (z Unią Europejską i Sojuszem Północnoatlantyckim) o wpływy w regionie poradzieckim, ale też projekcje wartości, nie tylko bezsprzecznie oddziałują na europejski system bezpieczeństwa, ale przede wszystkim zachwiały poczuciem bezpieczeństwa Polski. Ponadto dynamika przemian systemowych, ze względu na powiązania historyczno-kulturowe, ekonomiczne oraz geopolityczne warunkują zarówno obiektywne, jak i subiektywne postrzeganie stanu bezpieczeństwa definiowane między innymi w dokumentach strategicznych Polski.

Niepodważalną zaletą publikacji jest jej aktualność (choć konflikt na Ukrainie rozpoczął się w 2013 roku, to kryzys w tym państwie trwa już od ośmiu lat) oraz wielopłaszczyznowy charakter omawianej problematyki. 
Przedmiotem książki jest ocena wpływu kryzysu ukraińskiego na jakość bezpieczeństwa narodowego Polski w wymiarze politycznym i militarnym, w zdefiniowanej perspektywie czasowej. Ponadto Autor podejmuje próby analizy strategii i praktyki polityki zagranicznej Polski w warunkach kryzysu, a zwłaszcza wpływu zagrożeń militarnych na jej bezpieczeństwo. Przyjęto dość rozbudowane i wielowątkowe założenie badawcze o nierównowadze możliwości działań unilateralnych w razie wystąpienia konfliktu pomiędzy Polską a Rosją ze względu na dysproporcję potencjału militarnego obu stron. Ponadto Autor zakłada, że fundamentem bezpieczeństwa Polski w związku z tym są gwarancje sojusznicze. Oznacza to przewagę czynników jakościowych - politycznych nad ilościowymi - militarnymi. Uzasadnione jest zatem zastosowanie w publikacji syntezy obu wymiarów uwzględniających uwarunkowania międzynarodowe materii bezpieczeństwa perspektywy politycznego oddziaływania czynników militarnych na poziom bezpieczeństwa.

$\mathrm{Na}$ podkreślenie zasługuje gruntowanie opracowana przez Autora warstwa teoretyczno-metodologiczna podejmowanej problematyki, stanowiąca główną konstrukcję, swoisty szkielet, a nie tylko nadbudowę całości wielowymiarowych rozważań. Podejście to jest kompatybilne ze zdefiniowanym przez Autora celem, zakresem oraz problemami badawczymi. Osią pracy jest przyjęty paradygmat realistyczny oraz podejście neorealistyczne, czy realizm strukturalny, charakterystyczne dla analizy specyfiki wybranego modelu analitycznego - kryzysu ukraińskiego jako zagrożenia militarnego i jego wpływu na bezpieczeństwo Polski oraz wybranej perspektywy państwocentrycznej. Za słusznością przyjęcia paradygmatu realistycznego jako głównego podejścia poznawczego przemawia też obecność problematyki w dyskursie publicznym - zarówno politycznym, naukowym, jak i publicystycznym. Używane kategorie językowe i terminy analityczne (konflikt, kryzys, militaryzacja czy zagrożenie) sugerują, wręcz narzucają realistyczną pejoratywną (negatywną) metodologię. Jednocześnie należy się zgodzić z tezą Autora, że konflikt rosyjsko-ukraiński wyartykułował słabość i niezasadność zastosowania teorii liberalnych i związanych z nią pojęć wyjaśniających, takich jak soft, normative power na rzecz hard power w eksplanacji stosunków międzynarodowych w regionie Europy Wschodniej. Dało to wyraz w nieskuteczności formatu międzynarodowego zwanego normandzkim, w którym wyeliminowano podmioty pozapaństwowe, takie jak Unia Europejska, ograniczając się tylko do czterech państw uczestniczących w wypracowaniu zasad zakończenia konfliktu. Zastosowane podejście badawcze jest kompatybilne z założonymi tezami i hipotezą badawczą odnoszącą się do kryzysowej rzeczywistości międzynarodowej. Takie ujęcie problemu badawczego gwarantuje bogatą treść o wartości poznawczej, istotnej zarówno dla teorii, jak i praktyki politycznej.

Analiza pola badawczego została dokonana na czterech płaszczyznach: temporalnej, podmiotowej, przedmiotowej i przestrzennej. Cenzura czasowa podjętych badań została określona dość precyzyjnie w publikacji obejmując dążenia Ukrainy 
do integracji ze strukturami zachodnimi - od 21 listopada 2013 roku (początek kryzysu na Ukrainie od momentu odstąpienia prezydenta Wiktora Janukowycza od umowy stowarzyszeniowej z UE) do 1 września 2017 roku (wejścia w życie powyższej umowy). Jak podkreśla Autor, wyznaczony symbolicznie przedział czasowy obejmuje kluczowe dla problematyki wydarzenia. Ze względu na nieliniowość problematyki Bornio zastosował w książce retrospektywę - odniesienie się również do wydarzeń wcześniejszych osadzonych w uwarunkowaniach środowiska międzynarodowego.

Struktura książki jest przejrzysta i czytelna, choć bardzo rozbudowana. Publikacja składa się z siedmiu rozdziałów niezwykle bogatych w treść. Pierwsza część pracy poświęcona została rozważaniom teoretyczno-metodologicznym i definicyjnym - głównie jest to analiza kluczowych pojęć - problematyki bezpieczeństwa Polski w ujęciu podmiotowym i przedmiotowym $\mathrm{z}$ uwzględnieniem podstawowych szkół teoretycznych, pojęcia kryzys czy wojna hybrydowa, właściwych dla analizy obranego problemu badawczego. Kolejny rozdział poświęcono genezie kryzysu ukraińskiego z uwzględnieniem elementów dotyczących stosunków polsko-ukraińskich w perspektywie historycznej od lat dziewięćdziesiątych XX wieku do Euromajdanu w 2013 roku.

W rozdziale trzecim Autor kontynuuje obszerne rozważania wokół przebiegu i poszczególnych etapów kryzysu ukraińskiego na przykładzie wojny hybrydowej i stosowanej przez Rosję strategii właściwej temu pojęciu. Bazuje tu zarówno na wynikach prac autorów amerykańskich, ale też analityków rosyjskich zajmujących się tym obszarem badań. Cenny jakościowo jest zwłaszcza fragment poświęcony „operacji krymskiej” i ostatniej fazie - destabilizacji wschodniej Ukrainy. Ten wątek znajduje kontynuację w rozdziale czwartym $\mathrm{z}$ naciskiem na jego skutki dla bezpieczeństwa Polski i szerzej bezpieczeństwa międzynarodowego w kontekście rywalizacji Zachodu z Rosją.

W kolejnym rozdziale Autor skupił się na aktywności militarnej Rosji na przykładzie kryzysu ukraińskiego, ale też szerzej na zagrożeniach dla bezpieczeństwa państw zachodnich, mających źródło w geopolityce. Za szczególnie wartościową należy uznać analizę wpływu aktywności „okołokryzysowej” Rosji, a nie samego konfliktu, na bezpieczeństwo Polski. W rozdziale szóstym podjęto analizę reakcji świata zewnętrznego, głównie Sojuszu Północnoatlantyckiego i Stanów Zjednoczonych, na sytuację na Ukrainie, a zwłaszcza na zagrożenia militarne ze strony Rosji. Dokonano tu jednocześnie oceny skuteczności instytucji bezpieczeństwa w oddaleniu tych zagrożeń, nie pomijając wątku wkładu tych podmiotów w bezpieczeństwo regionu $\mathrm{w}$ formie wzmacniania wschodnich granic Polski przez amerykańską infrastrukturę wojskową (tak zwaną wschodnią flankę NATO).

Zamysłem Autora w ostatnim, siódmym rozdziale było wskazanie specyfiki relacji polsko-ukraińskich w kontekście kryzysu ukraińskiego a zwłaszcza wyzwań (wspólne inicjatywy wojskowe) i zagrożeń (destabilizacja Ukrainy) dla tych stosunków. W części podsumowującej Autor szczegółowo, zgodnie z przyjętym 
warsztatem, odnosi się do udzielenia odpowiedzi na postawione pytania, weryfikacji hipotez i wyników przeprowadzonych analiz problemu badawczego.

Koncepcja Autora dotycząca problematyki i ujęcia teoretycznego książki wpłynęła na dobór metod badawczych właściwych dla nauk o polityce oraz stosunków międzynarodowych. Zastosowane w pracy metody są typowe dla nauk społecznych - teoretyczne modus operandi wywodzące się z podejścia neorealistycznego - pochodzące z metody empirycznej myślenie przyczynowo skutkowe, metoda czynnikowa, podejście geopolityczne, metoda obserwacji, analiza krytyczna stanu badań, metoda opisowa. Zastosowano również właściwe techniki badawcze: analizę źródeł zarówno pisanych, jak i wypowiedzi i deklaracji politycznych, analizę badań i danych statystycznych. Autor wspierał się danymi statystycznymi między innymi przy analizie wyników procesu wyborczego. Należy pochwalić Autora za wzorowe wręcz panowanie nad zastosowanym bardzo rozbudowanym aparatem naukowym $\mathrm{w}$ postaci przypisów. W pracy pojawiają się przypisy rozszerzające i wyjaśniające główne treści.

Książka została napisana zrozumiałym, łatwym w odbiorze językiem, co jest szczególnie istotne $\mathrm{w}$ wymiarze popularnonaukowym pracy. Zdecydowanie należy docenić, że treści naukowe przedstawione są w sposób przystępny dla czytelników chcących poszerzyć swą wiedzę. Autor odsyła też do licznych źródeł.

Ze względu na walory poznawcze recenzowanej monografii z pełnym przekonaniem należy polecić publikację Jakuba Bornio osobom interesującym się omawianym obszarem, ale też wyrażającym troskę o bezpieczeństwo narodowe Polski. Wiele wartościowych informacji znajdą tam politolodzy, historycy dziejów najnowszych, badacze stosunków międzynarodowych. Recenzowana praca może stać się doskonałą pozycją dla studentów kierunków społecznych i humanistycznych.

Beata Piskorska ORCID: 0000-0002-9089-5156 Katolicki Uniwersytet Lubelski Jana Pawła II Lublin, 7.04.2021 r. 